\title{
Juridical Review of Validity of the Gross Split Sharing Contract Agreement in Oil and Gold Business Activities
}

\author{
M. Nabil Widhiantono ${ }^{1 *}$, Achmad Busro ${ }^{1}$, Ery Agus Priyono ${ }^{1}$ \\ Program Studi S1 Ilmu Hukum, Fakultas Hukum, Universitas Diponegoro \\ \{Widhiantononnbl@gmail.com ${ }^{1}$, achamd.busro@live.undip ${ }^{2}$,eryap@live.undip.ac.id ${ }^{3}$ \}
}

Fakultas Hukum, Universitas Diponegoro, Jl. Prof. H. Soedarto, S.H., Semarang, Indonesia $50275^{1}$

\begin{abstract}
This study aims to determine the validity status of the PSC Gross Split Scheme agreement following the Minister of Energy and Mineral Resources (ESDM) Regulation No. 8 of 2017 which regulates the refund of operating costs for the construction including goods, equipment, and land purchased by the Contractor that has been acquired becomes state property in conflict with Government Regulation (PP) No. 35 of 2004. The method used in this study is a normative legal method with descriptive research specifications, and qualitative analysis methods. This study concluded that the agreement did not meet the requirements of halal causes and still contains the principle of proportionality. The impact of not fulfilling the validity of the agreement will impact on the status of the agreement becomes null and void.
\end{abstract}

Keywords: Production Sharing Contract, Legal Terms of Agreement, Principle of Proportionality.

\section{Introduction}

\subsection{Background}

Natural Resources (Sumber Daya Alam/SDA) are all biological and non-biological resources that are used by human beings to find food and raw material for and energy needs.[1] SDA is divided into two, namely SDA that can be renewed and cannot be renewed.[2] Renewable natural resources are natural resources that can be reproduced both by natural factors and technology in a relatively short time, while non-renewable natural resources are natural resources that can be re-created in a very long time and are processed naturally. So the re-creation of natural resources requires thousands or even millions of years.

The natural resources have already been regulated in the Article 33 Paragraph 3 of the 1945 Constitution of the Republic of Indonesia.

Mohammad Hatta the author of this article explained that state control is not the state being a business actor but the state has the power to make regulations aimed at economic smoothness. These regulations are meant to prohibit the exploitation of weak people by people who have capital.[3], [4] One of the natural resources in Indonesia is Oil and Gas reserves. Oil and Gas in Indonesian Regulations and Regulations are regulated in Law Number 22 of 2001 concerning Oil and Gas.[5] The Oil and Gas Law divides oil and gas business activities into two namely upstream business activities and downstream business activities. Upstream 
business activities are activities that are full of risks and high costs and are carried out based on Cooperation Contracts as referred to in Article 6 paragraph 1 of the Oil and Gas Law.[6]

Cooperation Contracts in the Oil and Gas Law consist of Production Sharing Contracts and other contracts. The agreements commonly used in international practice. The contracts that are usually valid are Service Contracts, Pure Service Contracts, and Risk Contracts.[7]

Further provisions related to upstream business activities are regulated in PP No. 35 of 2004 Jo. PP No. 34 of 2005 Jo. PP No. 55 of 2009 concerning Upstream Business Activities.[8] PP No. 35 of 2004 regulates two types of cooperation contracts, namely Production Sharing Contracts (later known as Production Sharing Contracts/PSCs) and Service Contracts. Article 56 paragraph 2 PP No. 35 of 2004 provides provisions in the form of returning the operating costs for the Contractor in the Production Sharing Contract which came to be known as Cost Recovery. Cost Recovery itself aims to prevent the contractor's actions to acquire oil and gas production areas as if they belong to the Contractor because these costs have been reimbursed by the state.[9]

The Minister of Energy and Mineral Resources (ESDM) in 2017 issued Ministerial Regulation (Permen) Number 8 of 2017 which then underwent several changes namely ESDM Ministerial Regulation No. 52 of 2017 Jo. ESDM Ministerial Regulation No. 20 of 2019.[10] The ESDM Ministerial Regulation regulates the type of new Revenue Sharing Contract, namely the Gross Split Revenue Sharing Contract (PSC Gross Split Scheme). The Gross Split Production Sharing Contract explained in ESDM Regulation No. 8 of 2017 is a Production Sharing Contract in upstream business activities based on the principle of gross distribution without a mechanism for returning operating costs to the Contractor. The ESDM Ministerial Regulation was issued with one legal basis, Government Regulation No. 35 of 2004 so it is feared that there will be legal uncertainty because the Permen contradicts PP. This is not only a matter of the hierarchy of legislation but also be an issue in the realm of private law specifically regarding the status of agreements from the PSC Gross Split Scheme.

Article 1320 paragraph 4 of the Civil Code regulates the terms of the agreement in the form of a halal cause. Although the PSC Gross Split Scheme is based on the ESDM Ministerial Regulation, it contradicts the PP on Upstream Business Activities. So, it should be investigated whether the agreement still fulfills a halal reason or not. The thing that needs to be investigated is related to the principle of proportionality in the PSC Gross Split Scheme agreement in view of Article 21 of the ESDM Regulation No. 8 of 2017. It regulates that all goods and equipment purchased by the Contractor become state property and likewise with land that has been acquired as provided for in Article 22 paragraph 1 of the Ministerial Regulation. These provisions are felt to be unprofitable and tend to be burdensome for the Contractor. PSC Cost Recovery Scheme itself Every validity status of an agreement and the content of the proportionality principle in it certainly has an impact therefore the author also wants to do research on how the impact of the validity status of the PSC agreement in the Gross Split Scheme and content of the principle of proportionality in it. If the agreement does not meet the legal requirements of the agreement or does not contain the principle of proportionality in it, the author wants to examine how the legal impact of the agreement.

\subsection{Formulation of the Problem}

Based on the explanation above, there are three problems to be questioned in the study, namely:

1. Has the PSC Gross Split Scheme Cooperation Agreement made between the Special Task Force for Upstream Oil and Gas Business Activities (Satuan Kerja Khusus 
Pelaksana Kegiatan Usaha Hulu Minyak dan Gas Bumi/SKK Migas), and the Cooperation Contract Contractor fulfilled the legal requirements for the agreement?

2. Does the PSC Gross Split Scheme Cooperation Contract Agreement made between SKK Migas and the Cooperation Contract Contractor contain the principle of proportionality in it?

3. What is the impact of the legal or illegal status of the PSC Gross Split Scheme Cooperation Contract, and the content of the proportionality principle in it made between SKK Migas and the Cooperation Contract Contractor?

\section{Method}

The method used in this research is normative legal research with descriptive methods. Meanwhile, the data collection method of this research is the literature.

\section{Results and Discussion}

\subsection{Validity Analysis of Contracts for Profit Sharing in Gross Split Schemes Based on Legitimate Terms of Agreement.}

Article 1320 of the Civil Code requires that an agreement must fulfill four conditions, namely an agreement, a skill, an object that is promised, and a legal cause. An agreement is a conformity of statement of the will of the parties between one party and another party.[11] The Production Split Contract Agreement with the Gross Split Scheme has met the terms of the agreement, namely that the agreement is carried out in the form of signing at the end of the agreement text between the SKK Migas and the Cooperation Contract Contractor. The agreement takes place in the form of a will theory which occurs when the will of the recipient is stated.[12] The function of the signature itself in an agreement is as a sign of identity and a sign from the parties that signed it that they agreed to what was stated in the deed.[13]

The Gross Split Production Sharing Scheme Contract Agreement also meets the proficiency requirements. Legal subjects in civil law consist of people and legal entities.[14] Perpres No. 9 of 2013 Jo. Perpres No. 36 of 2018 gives the authority for SKK Migas to manage upstream oil and gas business activities based on a Cooperation Contract.[15] SKK Migas in this case is the party that gets the attribution from the delegated legislator namely the President to manage the upstream oil and gas business activities.[16] The party responsible for representing SKK Migas in the agreement is the Head of SKK Migas based on ESDM Regulation No. 17 of 2017 concerning the Organization and Work Procedure of SKK Migas provides the task for the Head of SKK Migas to represent SKK Migas in carrying out the duties and functions of the institution, one of which is the signing of the Cooperation Contract.[17]

The legal relationship that occurs in this agreement is a civil legal relationship between the government as a public legal entity represented by SKK Migas and the Cooperation Contract Contractor.[18] The government in this agreement abandoned its immunity as a sovereign state based on the concept of Iuri Gestiones.[19] The government, when making an 
agreement in private law, is considered to have been subject to the rules in private law as well as in the Cooperation Contract agreement.[20]

The object conditions agreed in the Gross Split Production Sharing Scheme Contract Agreement have also been fulfilled in the agreement. The object promised in an agreement is an object that becomes the obligation of the parties for an achievement that must be certain and can be counted.[21] Article 1333 paragraph 1 of the Civil Code stipulates that an agreement must have a principal of at least the type of goods that can be determined.

The object agreed in the Gross Split Production Sharing Scheme is the object that can be determined, namely an agreement to carry out a cooperation agreement between the Contractor and the Government of Indonesia (represented by SKK Migas). Therefore, the Contractor can carry out exploration and exploitation activities with the mechanism of gross production sharing without return operating costs. This is in accordance with Article 1.1.1. in the text of the Gross Split Production Sharing Contract template which stipulates that the contract is a Cooperation Contract in the form of a Gross Split Production Sharing Contract. The provisions in the agreement clause refer to ESDM Regulation No. 8 of 2017 Article 1 paragraph 7. The Production Sharing Contract itself is not a mechanism to transfer the state's right to control oil and gas wealth but is a means for the private sector to be able to participate in oil and gas mining activities.[22]

The object of the agreement can also be calculated because the template consisting Chapter I, Chapter, II, and Chapter VI regulates the amount of profit sharing for the parties and the duration of the contract which refers to the Oil and Gas Law and ESDM Ministerial Regulation on Production Sharing Contracts Gross Split Scheme. The term of the agreement is 30 years with a share of $57 \%$ of the state and $43 \%$ of the Contractor for oil production and $52 \%$ of the state and $48 \%$ of the Contractor for natural gas production which is then adjusted to the variable component and progressive component.

The final requirement to fulfill the legal conditions of the agreement is to see whether the agreement meets the requirements for a legal reason or not. Article 1337 of the Civil Code stipulates that an agreement becomes invalid if it contradicts the Statutory Regulations, decency, and public order. Non-fulfillment of these conditions makes the agreement null and void so that the agreement is considered to have never existed before.[23]

Production Sharing Contracts are based on concepts set out in the Oil and Gas Law and PP No. 35 of 2004. It is an agreement between the Government and the Cooperation Contract Contractor to give the Contractor the right to conduct upstream business activities on stateowned land provided. However, all risks and costs are borne by the contractor, and if the Contractor succeeds in finding commercial oil and gas reserves, it will be replaced by the state at the time of sharing production. These costs are in PP No. 35 of 2004 must obtain approval from SKK Migas at the work plan and budget stage.

The Gross Split Production Sharing Contract Agreement as stipulated in the ESDM Ministerial Regulation on the Gross Split Production Sharing Contract and in the draft text of the agreement is a production sharing contract in the upstream oil and gas business activities based on the principle of gross distribution without a mechanism of returning operating costs. The definition is certainly different from Article 56 paragraph 2 PP No. 35 of 2004 governing the provisions of the Contractor receives the costs they have incurred for the work plan and approved budget.

The principle of lex superior derogat lex inferior law states that if two legal rules are contradictory then what applies is a hierarchically higher regulation.[24] Hans Nawiasky, as quoted by Maria Farida, divides the legal norms in a country into four groups in sequence, namely the Staatsfundamentalnorm, Staatsgrundgesetz, Formell Gesetz, and Verordnung \& 
Autonome Satzung which, if compared to the laws and regulations in Indonesia sequentially, are then divided into Pancasila, the Constitution, and the Verordnung \& Autonome Satzung which. When implemented to the Laws and Regulations in Indonesia, it will be sequentially divided into Pancasila, the Constitution NRI 1945, Law, and finally PP, Perpres and Permen.[25]

ESDM Ministerial Regulation on Gross Split Production Sharing Contracts in the legal basis states that PP No. 35 of 2004 as one of the legal basis of the regulation. The legal basis in a statutory regulation is a juridical basis for the formation of a statutory regulation. [26] The draft script for the Gross Split Production Sharing Scheme also makes PP No. 35 of 2004 as one of the legal basis of the Contract, but the concept of the Production Sharing Contract of the Gross Split Scheme is different from the concept of the Production Sharing Contract stipulated in the PP on Upstream Business Activities.

The ideal provisions in the Gross Split Production Sharing Scheme agreement should be in line with the Statutory Regulations that form the legal basis, namely PP regarding Upstream Business Activities especially ESDM Ministerial Regulation on Contracts for Sharing in the hierarchy in terms of Legislation contrary to the Regulations in topped of that is PP. The Profit Sharing Contract of the Gross Split Scheme also fails to meet the four legal conditions of the agreement, which are legal reasons.

\subsection{Analysis of Principle of Proportionality in the Production Sharing Contract of the Gross Split Scheme.}

The evaluation of the content of the proportionality principle in the Gross Split Production Sharing Scheme Agreement done by the authors is by comparing the theory of the proportionality principle with the clauses set out in the text template of the Contract Split Profit Sharing Scheme. Agus Yudha Hernoko stated that a contract has the principle of proportionality if it contains four things, namely:[27]

1. The government gives contractors the same rights, opportunities and opportunities to find a fair exchange for the parties.

2. The parties are free to determine the substance that is fair and unfair to them.

3. The contract can guarantee the implementation of rights and at the same time the distribution of obligations proportionately to the parties to the agreement.

4. In terms of a dispute in the agreement, the burden of proof and other related matters must be measured based on the principle of proportionality so as to produce a solution that benefits both parties.

The author argues that the core of criteria number one and two is to give freedom to the parties only theory number one emphasizes the condition or position of the parties while in theory number two places more emphasis on the substance of the contract.

The form of the Production Sharing Contract of the Gross Split Scheme is a standard agreement because it has provided a draft agreement document. A standard agreement is an agreement in which almost all the contents of the agreement have been determined by one of the parties and the clauses which have not been determined are only related to certain matters.[28], [29] Although the Contractor is not the party who will compile the contents of the Gross Split Production Sharing Scheme Agreement, this does not mean that the agreement does not reflect the freedom of the parties in it. This is because upstream business activities must be viewed in terms of private and public law so that it is the duty of the state to protect 
all Indonesian people, one of them is by standardizing the text of the Gross Split Production Sharing Scheme in order to protect Indonesia's natural wealth.

The second criterion related to the exchange of rights and obligations of the parties, in this case the author feels the provisions stipulated in Article 5.2. in the template of the agreement concerning the obligation for the Contractor to provide funds and purchase or lease all equipment, equipment and materials needed to be purchased or leased using rupiah or foreign currency according to the contractor's work plan. This is due to the fact that Chapter X stipulates that all ownership rights to goods, equipment purchased by the Contractor for upstream oil and gas business activities will become state property as well as land acquired. This provision seems to burden the Contractor because it is the Contractor who buys goods and equipment and conducts land acquisition so that it is ideally owned by the Contractor.

The reality that happens is that goods, equipment, and land that have been acquired must belong to the state because it is the one that finances all of these things. Funding by the state is carried out not by reimbursing operating costs as the Cost Recovery Scheme of Production Sharing Contracts, but financing is done by the state distributing production results to the Contractor from the products of which state ownership is actually owned. The division of production output for the Contractor by $43 \%$ for oil and $48 \%$ for natural gas is not merely sharing its ownership in oil and gas, but based on the results of the research conducted by the author in the form of an interview also accompanied by the intention that the Contractor can finance its operational activities from the distribution of production results.

The conclusion is that the goods, equipment, and land must indeed belong to the state and this does not violate the principle of proportionality. The Gross Split Production Sharing Contract Agreement regulates the mechanism if there is a dispute that occurs in the implementation of the agreement. The principle of proportionality requires that the resolution of disputes, the burden of proof, the severity of errors and other matters must be measured proportionally so as to produce an elegant and win-win solution. This is evidenced by Article 11.2 and Article 11.3 of the draft agreement text regulating that if a dispute occurs it is deliberated and if it fails to be carried out by deliberation it will be resolved at the Indonesian National Arbitration Board (BANI).

Deliberation is one of the communalistic characteristics of Indonesian society that is commonly practiced by Indonesian people to solve problems together.[28] The provisions stipulated in Article 11 of the draft agreement text reflect proportional dispute resolution criteria because of trying to find a win-win solution.[28]

\subsection{Analysis of the Impact of the Validity of the Agreement and the Content of the Proportionality Principle in the Agreement.}

The author believes that when an agreement does not contain the principle of proportionality, that is due to the agreement does not provide recognition related to the opportunity and proportional position to the parties to freely determine the substance in a fair way. Therefore, the agreement violates the provisions of Article 1320 paragraph 1 of the Civil Code. The agreement can also be considered to violate Article 1320 paragraph 4 of the Civil Code in terms of halal conditions if the agreement contains clauses that conflict with public order or violate the Laws and Regulations prohibiting incriminating one party as an example of the Law on Consumer Protection.

The impact of not fulfilling the legal requirements of the agreement in the Gross Split Production Sharing Scheme Agreement makes the agreement not have legal force as regulated in Article 1335 of the Civil Code. The parties to the agreement cannot sue for arbitration to 
decide that the other party must fulfill their achievements because the agreement was deemed never to exist.[29]

Conditions that occur if the Gross Split Production Sharing Scheme Agreement has met the legal requirements of the agreement also does not make the agreement free from legal issues. This is because there is no separation of assets between SKK Migas and the Government of Indonesia due to the legal basis for the establishment of SKK Migas not to mention SKK Migas as an independent legal entity with assets separate from state assets.

\section{Conclusion}

Firstly, the Gros Split Scheme Sharing Production Agreement does not meet the requirements of the validity of the agreement. In this case, it does not meet the requirements for halal reasons. The concept stipulated in the Gross Split Production Sharing Scheme in the Minister of Energy and Mineral Resources Regulation and the agreement template found to be different than the one on PP No. 35 of 2004. Therefore, it can be said to be contrary to legal reasons.

Secondly, the Gross Split Production Sharing Scheme agreement still contains the principle of proportionality in the agreement. The state of governing all goods, equipment, and land purchased by the Contractor, in which the acquisition has been acquired becomes state property does not mean that it will harm the Contractors. In fact, they already obtained funding from the state to carry out its operations even if it is not in the form of returning operating costs.

Third, the status of the Gross Split Production Sharing Scheme agreement is a null and void agreement. The parties to this agreement cannot make demands that the other party fulfill its performance in arbitration. 


\section{References}

[1] A. Fauzi, Ekonomi sumber daya alam dan lingkungan: Teori dan aplikasi. Jakarta: Gramedia Pustaka Utama, 2004.

[2] Y. Pongtuluran, Manajemen sumber daya alam dan lingkungan. Yogyakarta: Penerbit Andi, 2015.

[3] M. Hatta, R. Abdulgani, and M. Saleh, Penjabaran Pasal 33 Undang-Undang Dasar 1945. Jakarta: Mutiara, 1977.

[4] J. R. Mawuntu, "Konsep penguasaan negara berdasarkan pasal 33 UUD 1945 dan putusan mahkamah konstitusi," J. Huk. Unsrat, vol. 20, no. 3, pp. 11-21, 2012.

[5] Law Number 22 of 2001 concerning Oil and Gas. .

[6] M. I. F. Putuhena, "Politik Hukum Pengelolaan Hulu Migas Pasca Putusan Mahkamah Konstitusi," J. Rechts Vinding Media Pembin. Huk. Nas., vol. 4, no. 2, pp. 237-253, 2015.

[7] I. H. Ikasari, "Influence of Psc Changes in the Upstream Sector from Cost Recovery System into Gross Split toward the Obligation to Pay Land Building Tax," Mimb. Hukum-Fakultas Huk. Univ. Gadjah Mada, vol. 3, no. 1, pp. 126-139.

[8] Government Regulation Number 35 of 2004 concerning Upstream Oil and Gas Business Activities Jo. Government Regulation Number 34 of 2005 Jo. Government Regulation Number 55 of 2009. .

[9] S. Shobah, "Cost Recovery dalam Kontrak Kerjasama Minyak dan Gas Bumi di Indonesia Ditinjau dari Hukum Kontrak Internasional," Kumpul. J. Mhs. Fak. Huk., vol. 4, no. 2, 2015.

[10] "ESDM Minister Regulation No. 8 of 2017 concerning Gross Split Production Sharing Contract Jo. ESDM Minister Regulation Number 52 of 2017 Jo. ESDM Minister Regulation Number 20 of 2019."

[11] S. Hajati, E. D. Poespasari, and O. Moechthar, Buku Ajar Pengantar Hukum Indonesia. Surabaya: Airlangga University Press, 2019.

[12] M. D. Badrulzaman, Hukum Harta Kekayaan di Indonesia. Bandung: Citra Aditya Bakri, 2008.

[13] E. K. Kotimah and L. Santoso, "Urgensi Tanda Tangan dan Materai dalam Memberikan Kepastian Hukum terhadap Kontrak Waralaba (Franchise)," Halu Oleo Law Rev., vol. 1, no. 1, pp. 43-63, 2018.

[14] Subekti, Pokok-Pokok Hukum Perdata. Jakarta: Intermasa, 2017.

[15] Presidential Regulation Number 9 of 2013 concerning Management of Upstream Oil and Gas Business Activities Jo. Presidential Regulation Number 36 of 2018. .

[16] R. H. R., Hukum Administrasi Negara. Jakarta: Raja Grafindo Persada, 2016.

[17] ESDM Minister Regulation No. 17 of 2017 concerning the Organization and Work Procedures of Special Work Units for Upstream Oil and Gas Business Activities. .

[18] M. C. Mahulette, D. Hartono, and J. Priyono, "Status Production Sharing Contract Ditinjau dari Konvensi Wina 1969 dan Undang-undang Dasar 1945," Diponegoro Law J., vol. 5, no. 2, pp. 1-13, 2016.

[19] F. Kurniawan, "Bentuk Perlindungan Hukum Terhadap Kekayaan Minyak dan Gas Bumi Sebagai Aset Negara Melalui Instrumen Kontrak,” Perspektif, vol. 18, no. 2, pp. 74-85, 2013.

[20] A. Busro, Kapita Selekta Hukum Perjanjian. Yogyakarta: Pohon Cahaya, 2013.

[21] A. Saleng, "Hubungan Hukum Antara Pemerintah Dengan Badan Usaha Swasta Dalam Berbagai Pola Kontrak Kerjasama Pengusahaan Pertambangan,” J. Huk. IUS 
QUIA IUSTUM, vol. 7, no. 13, pp. 12-30, 2000.

[22] I. R. Widjaya, Merancang Suatu Kontrak Teori dan Praktek. Bekasi: Kesaint Blanc, 2004.

[23] J. Effendi, I. G. Widodo, and F. F. Lutfianingsih, Kamus Istilah Hukum Populer. Jakarta: Paramedia Group, 2016.

[24] M. Farida, Ilmu Perundang-Undangan I. Yogyakarta: Kanisius, 2007.

[25] M. Farida, Ilmu Perundang-Undangan II. Yogyakarta: Kanisius, 2017.

[26] A. Y. Hernoko, Hukum Perjanjian: Asas Proporsionalitas dalam Kontrak Komersial. Jakarta: Kencana, 2010.

[27] S. R. Sjahdeini, Kebebasan Berkontrak dan Perlindungan yang Seimbang bagi Para Pihak dalam Perjanjian Kredit Bank di Indonesia. Jakarta: Institut Bankir Indonesia, 1993.

[28] N. V. Ariani, “Alternatif penyelesaian sengketa bisnis di luar pengadilan," J. Rechts Vinding Media Pembin. Huk. Nas., vol. 1, no. 2, pp. 277-294, 2012.

[29] H. Erawati, E. and Budiono, Penjelasan Hukum Tentang Kebatalan Perjanjian. Jakarta: Gramedia Pustaka Utama, 2010. 